\title{
What is a moth doing under water? Ecology of aquatic and semi-aquatic Lepidoptera
}

\author{
Krzysztof Pabis* \\ Department of Invertebrate Zoology and Hydrobiology, University of Lodz, Banacha 12/16, 90-237 Lodz, Poland
}

\begin{abstract}
This paper reviews the current knowledge on the ecology of aquatic and semi-aquatic moths, and discusses possible pre-adaptations of the moths to the aquatic environment. It also highlights major gaps in our understanding of this group of aquatic insects. Aquatic and semi-aquatic moths represent only a tiny fraction of the total lepidopteran diversity. Only about $0.5 \%$ of 165,000 known lepidopterans are aquatic; mostly in the preimaginal stages. Truly aquatic species can be found only among the Crambidae, Cosmopterigidae and Erebidae, while semi-aquatic forms associated with amphibious or marsh plants are known in thirteen other families. These lepidopterans have developed various strategies and adaptations that have allowed them to stay under water or in close proximity to water. Problems of respiratory adaptations, locomotor abilities, influence of predators and parasitoids, as well as feeding preferences are discussed. Nevertheless, the poor knowledge on their biology, life cycles, genomics and phylogenetic relationships preclude the generation of fully comprehensive evolutionary scenarios.
\end{abstract}

Keywords: Lepidoptera / Acentropinae / caterpillars / freshwater / herbivory

Résumé - Que fait une mite sous l'eau? Écologie des lépidoptères aquatiques et semi-aquatiques. Cet article passe en revue les connaissances actuelles sur l'écologie des mites aquatiques et semi-aquatiques, et discute des pré-adaptations possibles des mites au milieu aquatique. Il met également en lumière les principales lacunes dans notre compréhension de ce groupe d'insectes aquatiques. Les papillons aquatiques et semi-aquatiques ne représentent qu'une infime fraction de la diversité totale des lépidoptères. Seulement $0,5 \%$ environ des 165,000 lépidoptères connus sont aquatiques, principalement aux stades préimaginaux. On ne trouve des espèces véritablement aquatiques que chez les Crambidés, les Cosmopterigidés et les Erebidés, tandis que les formes semi-aquatiques associées aux plantes amphibies ou des marais sont connues dans treize autres familles. Ces lépidoptères ont développé diverses stratégies et adaptations qui leur ont permis de rester sous l'eau ou à proximité de l'eau. Les problèmes d'adaptation respiratoire, les capacités locomotrices, l'influence des prédateurs et des parasitoïdes, ainsi que les préférences alimentaires sont discutés. Néanmoins, le manque de connaissances sur leur biologie, leur cycle de vie, leur génomique et leurs relations phylogénétiques empêche l'élaboration de scénarios évolutifs complets.

Mots-clés : Lépidoptères / Acentropinae / chenille / eau douce / herbivorie

\section{Introduction - from the water onto the land and back again}

All insects are primarily terrestrial. However, it is worth bearing in mind that they have evolved from aquatic invertebrates. According to the pancrustacean theory, insects evolved from crustaceans, with the Remipedia being the most probable sister group of the Hexapoda. Therefore, crustaceans

\footnotetext{
${ }^{*}$ Corresponding author: cataclysta@wp.pl
}

can be said to have colonized the land as insects. According to the latest estimates the terrestrial colonization happened sometime between the late Cambrian and early Ordovician (Schwentner et al., 2017). The enormous radiation of insects in the terrestrial ecosystems resulted in a high level of adaptation to life on land. These adaptations included the ability to fly and the development of a tracheal system. However, all those fantastic adaptations that made the insects the most successful terrestrial animals on our planet imparted important restrictions on the exploration of waters; a process certainly 
associated with substantial modifications of locomotor abilities, mating systems, feeding modes, respiratory and sensory adaptations. In addition, these early insect colonists had to compete with already established inhabitants of the water world (Ward, 1992; Vermeij and Dudley, 2000).

Aquatic or semi-aquatic species can be found in 16 orders of insects (Ward, 1992). All of them have terrestrial ancestors, which have independently colonized the waters. Sometimes, the aquatic mode of life has evolved multiple times within an insect order (Grimaldi and Engle, 2005). Although as few as about $6 \%$ of all insects are found in the aquatic environment, they account, according to the latest estimates, for $60 \%-80 \%$ of all the freshwater animals (Dijkstra et al., 2014). The Lepidoptera are represented by a relatively low number of species compared with other aquatic insect orders. Although our knowledge on their diversity and taxonomy is constantly increasing (Landry and Roque-Albelo, 2006; Mey and Speidel, 2008; Chen et al., 2010; Agassiz, 2012, 2014; Scholtens and Solis, 2015), there is a lot yet to be learned about the ecology and possible evolutionary scenarios or phylogenetic relationships that exist among the aquatic and semi-aquatic Lepidoptera.

\section{What are aquatic and semi-aquatic moths?}

Among the 165,000 currently described Lepidoptera, only about $0.5 \%$ of the species (representing three families) are considered to be truly aquatic. Their caterpillars are generally believed to live entirely submerged. Most of the species of truly aquatic Lepidoptera belong to the family Crambidae (about 800 species of the Acentropinae, representing over 50 genera, and at least two species in the genera Samea and Niphograpta of the subfamily Pyraustinae) (Mey and Speidel, 2008). Mey and Speidel (2008) reviewed the information regarding the species richness of aquatic Crambidae, but they did not analyse the problems associated with the ecology of this group. It is worth remembering that the biology of the immature stages of numerous species of Crambidae is completely unknown. It can only be assumed that some species are aquatic based on their systematic position within the subfamily Acentropinae. On the other hand, larvae of some Acentropinae (in the genera Nymphicula, Paracymoriza, and Aulacodes) are terrestrial (Regier et al., 2012), but it is not clear whether they represent reversions or ancestral adaptations. In the case of Nymphicula, Yoshiyasu (1980) suggested based on the morphology of the caterpillar tubes that this genus might represent a reversion from an aquatic to a terrestrial mode of life, but without detailed molecular studies it is difficult to confirm the validity of this hypothesis. Some other aquatic crambids like larvae of Petrophila truckeealis are able to live for several days outside the water (Lange, 1971), which suggests that the diversity of strategies is probably much higher than we expect. There are also at least four species of aquatic arctiid moths. Larvae of Paracles laboulbeni live in the South American lakes and feed on Oedogonium, various Bacillariophyta and, at later stages, on Utricularia olivacea (Adis, 1983). Three of the other neotropical species of the genus Paracles: P. klagesi (associated with Tonina fluviatilis and some other plants), P. azollae and P. burmeisteri also develop in freshwater (Meneses et al., 2013). Large numbers of aquatic species, most of which are still undescribed represent the genus Hyposmocoma (Cosmopterigidae), which is endemic to Hawaii (Schmitz and Rubinoff, 2011).

Various caterpillars of Lepidoptera live in stems or roots or on exposed and non-submerged leaves of semi-aquatic or marsh plants such as: Typha, Glyceria, Carex, Phragmites, Sparganium or Scirpus. Such species are known from various families and genera (Table 1). Mey and Speidel (2008) treated all similar taxa as semi-aquatic and did not include them in their review. Nevertheless, it is also worth remembering that it is occasionally difficult to clearly differentiate between aquatic and semi-aquatic forms; for example the caterpillar of noctuid Bellura melanopyga periodically comes to the surface to renew its oxygen supply (Lange, 1956). On the other hand, some Acentropinae, e.g. the common European Nymphula nitidulata that lives on Sparganium erectum represents a semi-aquatic rather than a truly aquatic Lepidoptera (Vallenduuk and Cuppen, 2004).

According to rough estimates, there are about 500,000 lepidopteran species worldwide (Kristensen et al., 2007; Brito et al., 2016 end references therein). The number of undescribed species is huge. Moreover, the biology and habitat preferences of numerous formally described species, especially tropical lepidopterans, are completely unknown. Therefore, more aquatic and semi-aquatic forms can be expected to be found in other families, in both the Macro- and Microlepidoptera.

\section{From the surface to the depths - evolutionary potential of aquatic caterpillars}

Generally, lepidopteran caterpillars are not typical inhabitants of the aquatic environment. However, they are associated with a great variety of habitats, including those that are moist or wet. Some of the caterpillars live in moist soil (Grimaldi and Engle, 2005) or inside pitcher plants (Scoble, 1995), while others - such as some of the Hawaiian Hyposmocoma inhabit streams where they feed on algae covering wet rocks. However, they can also complete their whole life cycle outside of a water body (Rubinoff, 2008). An evolutionary step from such moist habitats to a fully aquatic lifestyle seems to be possible. Even more interesting transitions to the aquatic mode of life have been observed in other insect orders, for example, a nitidulid beetle has changed its habitat from bamboo sap to freshwater (Kovac et al., 2007).

It should not then be surprising to assume that similar events might also have occurred among the Lepidoptera. Some adaptations to moisture or periodic flooding were already reported from the phylogenetically most basal lepidopteran groups such as the Micropterigidae. For example, caterpillars of the genus Epimartyria from North America live in swampy woods or boggy ditches and are known to have micropapillae on their cuticle. These micropapillae form a simple plastronlike respiration system (Davis and Landry, 2012). Thus, this suggests that moth caterpillars already had the evolutionary potential to enter the aquatic milieu at the beginning of their evolutionary history.

Various pre-adaptations, typical of many terrestrial caterpillars were most probably very important for the evolution of the aquatic life style. The underwater breathing 
Table 1. Moth genera with representants associated with various amphibious and marsh plants.

\begin{tabular}{|c|c|c|}
\hline Family/genus & Plant genera & References \\
\hline Coleophoridae: Coleophora & Juncus, Polygonum & $\begin{array}{l}\text { Harms and Grodowitz (2009); Sterling and } \\
\text { Parsons (2012) }\end{array}$ \\
\hline Cosmopterigidae: Cosmoptrix, Limnaecia & Phragmites, Typha & $\begin{array}{l}\text { Harms and Grodowitz (2009); Sterling and } \\
\text { Parsons (2012) }\end{array}$ \\
\hline Cossidae: Phragmatecia & Phragmites & Carter and Hargreaves (1994) \\
\hline Crambidae (Crambinae): Acigona, & Eleocharis, Juncus, Schoenoplectus, & Slamka (1997); Harms and Grodowitz \\
\hline $\begin{array}{l}\text { Calamotropha, Chilo, Occidentalia,Thopeutis } \\
\text { Crambidae (Schoenobiinae): Donacaula, } \\
\text { Schoenobius Scirnonhood }\end{array}$ & $\begin{array}{l}\text { Scirpus, Typha } \\
\text { Carex, Glyceria, Phragmites, Scirpus }\end{array}$ & $\begin{array}{l}\text { (2009); Sterling and Parsons (2012) } \\
\text { Slamka (1997); Vallenduuk and Cuppen }\end{array}$ \\
\hline $\begin{array}{l}\text { Schoenobius, Scirpophaga } \\
\text { Elachistidae: Elachista }\end{array}$ & Phragmites & $\begin{array}{l}\text { (2004) } \\
\text { Sterling and Parsons (2012) }\end{array}$ \\
\hline Erebidae (Arctiinae): Estigmene & Polygonum & Harms and Grodowitz (2009) \\
\hline Erebidae (Herminiinae): Palthis & Polygonum & Harms and Grodowitz (2009) \\
\hline Erebidae (Hypenodinae): Hypenodes & Carex, Juncus, Sparganium & Nowacki (1998) \\
\hline Erebidae (Lymantriinae): Laelia & Cladium, Phragmites, Sparganium & Carter and Hargreaves (1994) \\
\hline Gelehiidae: Aristotelia, Brachmia Chionodes & Phragmites, Polygonum & Harms and Grodowitz (2009) \\
\hline Glyphipterigidae: Glyphipterix & Juncus & Sterling and Parsons (2012) \\
\hline Nepticulidae: Stigmella & - & Lange (1956) \\
\hline $\begin{array}{l}\text { Noctuidae: Acronicta, Apamea, Archanara, } \\
\text { Argyrogramma, Bellura, Capsula, Celaena, } \\
\text { Cerapteryx, Chilodes, Coenobia, } \\
\text { Homophoberia, Neoerastria, Nonagria, } \\
\text { Oligia, Plusia, Rhizedra, Sedina, Simyra, } \\
\text { Spodoptera }\end{array}$ & $\begin{array}{l}\text { Carex, Eichhornia, Glyceria, Juncus, } \\
\text { Nelumbo, Nuphar, Nymphaea, } \\
\text { Phragmites, Pistia, Polygonum, } \\
\text { Pontederia, Sagittaria, Scirpus, } \\
\text { Sparganium, Typha, Zizania }\end{array}$ & $\begin{array}{l}\text { McGaha (1954); Carter and Hargreaves } \\
\text { (1994); Nowacki (1998); Wheeler and } \\
\text { Halpern (1999); Center and Hill (2002); } \\
\text { Harms and Grodowitz (2009) }\end{array}$ \\
\hline Pyralidae: Dicymolomia, Sylepta & Polygonum, Typha & Harms and Grodowitz (2009) \\
\hline Sphingidae: Eumorpha & Ludwigia & $\begin{array}{l}\text { Harms and Grodowitz (2009), Lange 1956; } \\
\text { Lange (1971); Ward (1992) }\end{array}$ \\
\hline Tineidae & - & Lange (1956); Lange (1971); Ward (1992) \\
\hline $\begin{array}{l}\text { Tortricidae: Argyrotaenia, Bactra, } \\
\text { Choristoneura Platynota Sparganothis }\end{array}$ & $\begin{array}{l}\text { Juncus, Polygonum, Schoenoplectus, } \\
\text { Scirnus Typha }\end{array}$ & $\begin{array}{l}\text { Harms and Grodowitz (2009); Sterling and } \\
\text { Parsons (2012) }\end{array}$ \\
\hline $\begin{array}{l}\text { Choristoneura, Platynota, Sparganothis } \\
\text { Yponomeutidae: Orthotaelia }\end{array}$ & $\begin{array}{l}\text { Scirpus, Typha } \\
\text { Schoenoplectus, Sparganium, Typha }\end{array}$ & \\
\hline
\end{tabular}

mode most probably began to develop from the aforementioned cuticle pre-adaptations. A collapsible air bubble (a physical gill) that allows diving and requires regular air supply restoration is a very common adaptation in this group (Lange, 1956; Speidel, 2002). A further improvement of this mechanism could have led to the evolution of a more efficient plastron structures which allowed for further exploration of the aquatic environment and may have enabled longer stays under water. For example, caterpillars of the genus Paracles developed a unique plastron system from long clavate hairs that covered the larval body (Messner and Adis, 1987; Meneses et al., 2013). Cuticle hydrophobicity can be enhanced by various waxy substances, hairs, or cuticular surface structures (Reichholf, 1976; Ward, 1992). Although the hydrophobic cuticle is known in aquatic moths larvae, such adaptations can be found in many typically terrestrial caterpillars representing various families of Lepidoptera. The hydrophobic cuticle prevents the caterpillar from getting and staying wet since the water can simply slide off the body (Balmert et al., 2011). Developing a relatively stable air bubble around the body can be facilitated by the presence of tubes made of leaves of the host plants or made from the debris of various plants (Pabis, 2014). This is another typical feature of many terrestrial lepidopteran larvae. These tubes of aquatic caterpillars enhance respiration and protect the caterpillar from UV radiation (Dorn et al., 2001). These tubes also provide at least some protection from predators or parasites (Müeller and Dearing, 1994).

Development of the hydrophilic cuticle and of the closed spiracle system allowed for respiration based on waterdissolved oxygen diffusing through the cuticle. This adaptation enhanced exploration of the deeper areas, like in the case of Acentria ephemerella (Berg, 1941). It is still not clear which adaptation appeared earlier and which can be treated as a more advanced. There are species of Acentropinae that are hydrophilic during the first stages of development and become hydrophobic later on during development. Caterpillars of some other species are hydrophilic during all the larval stages (Speidel, 2002). Moreover, typical hydrophilous caterpillars may also construct protective cases (Berg, 1941). Some lepidopteran larvae developed tracheal gills that can be aided by periodic vibratory movements, which probably enhances the air supply (Welch and Sehon, 1928). Hawaiian aquatic Hyposmocoma most probably breathe directly through the cuticle and need well oxygenated running water. They will die if they are in still water (Schmitz and Rubinoff, 2011). 
In contrast to the respiratory systems, aquatic caterpillars did not develop any special or particularly efficient locomotor adaptations to living in the aquatic environment. Generally, caterpillars are not very good swimmers. Although larvae of the crambid Ostrinia penitalis may swim on the water surface and may also use a dragline made of silk (Welch, 1919). Aquatic caterpillars generally move in a manner that is very similar to that seen in the terrestrial forms (they use thoracic legs and prolegs with crochets). Aquatic caterpillars can be found almost exclusively on plants they feed on, or on algaecovered surfaces. None of the known caterpillars found associated with water developed any special swimming legs such as are evident in many aquatic adult beetles or aquatic hemipterans. Despite the very diverse caterpillar morphology, the basic body plan is very conservative and the legs even if modified for some reason (e.g. Stauropus fagi, or carnivorous Hawaiian caterpillars) do not differ radically in their locomotor functions (Grimaldi and Engle, 2005). Perhaps this is one of the most important evolutionary limitations that did not allow for the evolution of active swimming. Furthermore, the general caterpillar body plan probably precludes the development of a more streamlined shape. In addition, insect bodies tend to sink in water because their density is only slightly higher than that of water (Flynn and Bush, 2008). To be able to actively swim under water insects should combine morphological adaptations (e.g. swimming legs) with air bubbles that enhance their buoyancy. Aquatic caterpillars are often associated with stagnant waters or slow-flowing rivers. Even when they live in streams, they do not develop any swimming adaptations that would enable them to move actively through the water column (Lange, 1956; Ward, 1992; Stoops et al., 1998). Some, like the North American species of Petrophila and Argyractis, do inhabit streams, but they are protected from being carried away by the currents by having types of silken tents that are attached to the stones on the bottom of the stream (Lange, 1956; Lange, 1971).

Adaptations associated with diet were also probably very important for the evolution of an aquatic mode of life in the caterpillars. Exactly like truly terrestrial forms, aquatic and semi-aquatic caterpillars include scrapers (often with flattened and enlarged mandibles), algae feeders and typical leaf shredders associated with angiosperms (Lange, 1956; Mey and Speidel, 2008). Some free-living caterpillars that are algae scrapers could have evolved from soil-dwelling forms (Grimaldi and Engle, 2005; Davis and Landry, 2012). Of the typical plant-feeding lepidopteran larvae, stem borers and typical external feeders were probably among the first colonizers of aquatic environment (Ward, 1992; Grimaldi and Engle, 2005). Is often assumed that the first aquatic plant feeders had initially no real contact with water since they were hiding inside of plant tissues or foraging only on the emergent parts of plants that were above the water surface (Hannemann, 1967; Ward, 1992; Mey and Speidel, 2008). Some known terrestrial species possess unusual abilities that could be similar to the first basic adaptations that occurred in the aquatic environment. For example, caterpillars of the arctiid moth Rhyparioides metelkana feed on Caltha palustris and are able to swim to another plant when they accidentally fall into the water (Hannemann, 1967). Larval stages of the arctiid moth, Spilosoma lubricipeda that normally feed on Menta or Rubus were also occasionally observed on the water pineapple,
Stratiotes aloides, and were also able to swim to another plant. However, all the pupae died at the end of the season when the water pineapple sank to the bottom of the water body (Smolders and van der Velde, 1996). A common polyphagous pest Duponchelia fovealis is known to consume various plants from 38 families, including at least one aquatic plant - a water-trumpet (Cryptocoryne) (Brambila and Stocks, 2010). This suggests that polyphagy might have been an important first step in the early evolution of aquatic moths and probably allowed caterpillars to switch to the aquatic plants as a food source.

The influence of a caterpillar's feeding experience (first species of plant used by newly hatched caterpillar) on its host plant preferences (host plant induction, level of specialization and its relation to plant chemical defences) could also be important for the evolution of aquatic and semi-aquatic moths, but there are almost no data on such processes (Litsinger and Chantarapraha, 1995; Wheeler and Halpern, 1999; Dorn et al., 2001; Erhard et al., 2007; Petit et al., 2015). Walenciak et al. (2002) and Choi et al. (2002) reported that macrophytes containing tannin may possibly alter the performance of $A$. ephemerella caterpillars indirectly by an inhibitory effect on their gut microbiota. Since symbiotic bacteria can be very important in the evolution of Lepidoptera (Russell et al., 2012), further studies in this area are urgently needed in aquatic moths. Both, prior feeding experience, and plant chemical cues have increased the preference of the Munroessa gyralis caterpillar for Nuphar. However, protein content, concentration of polyphenols and leaf toughness were found to not be as important in influencing food preference in Munroessa gyralis (Dorn et al., 2001). At the same time none of the larvae managed to pupate, neither on Nuphar nor on the normally preferred Nymphaea. This might suggest that larvae require a mixed diet or that the conditions provided in the experiments were inappropriate. Authors also speculated that Nuphar petioles might be too small to serve as a pupation site for the caterpillars. This study of the one species shows how complex such interactions might be. Caterpillar preferences can depend on many factors, including the influence of predators, development time of the plant, or its various chemical or morphological features. Such relationships may vary depending on the species or genus of moth; moreover, the first generation caterpillars might have different preferences compared with the second generation caterpillars. Elophila obliteralis may feed on about 60 species of plants, including such different taxa as Lemna, Sagittaria, Myriophyllum or Hydrochloa (Habeck et al., 2017). However, we do not know much about the mechanisms involved in shaping preferences for a specific plant species. We also do not know about the caterpillar development time and survival rates on different plant species. On the other hand some oligophagous species, like Cataclysta lemnata, a crambid that was generally found to be associated with Lemnaceae, may occasionally consume other macrophytes including Stratiotes aloides, or even Typha latifolia and Glyceria maxima (van der Velde, 1988), as well as water ferns of the genus Azolla (Farahpour-Haghani et al., 2017). Stoops et al. (1998) suggested, based on their own results and literature data that most of the aquatic crambids are polyphagous since they feed on more than four species of plants from a minimum of three plant families. A wide host range of aquatic caterpillars might have been important in the 
evolution of the aquatic and semi-aquatic moths taking into account the fact that the number of aquatic angiosperms in freshwater is much lower than is found in terrestrial environment (Chambers et al., 2008). On the other hand such generalisations should be made with caution, since we do not know much about the diet of the majority of the aquatic moths.

\section{Ecological interactions}

There is a common notion that aquatic caterpillars play a relatively minor role in the ecological interactions of freshwater ecosystems. However, those opinions are often based on the underestimations of the importance of Lepidoptera and there is also a lack of even basic knowledge about their diversity and abundance. Aquatic caterpillars are definitely an important group of aquatic herbivores. In fact, some species were noted to occur at very high densities in aquatic ecosystems. For example, the abundance of A. ephemerella caterpillars may sometimes reach 10,000 ind. $/ \mathrm{m}^{2}$ (Gross et al., 2002). Lepidopteran caterpillars may also influence the species composition of macrophytes, which might result in important changes in the functioning of the ecosystem (Gross et al., 2001). Some of the caterpillars can probably also be used as indicators of changes in natural ecosystems. Such ecosystems could include the Hawaiian streams, a habitat that lacks typical aquatic insect indicators such as trichopterans and ephemeropterans (Schmitz and Rubinoff, 2011). It was also demonstrated that larvae of Parapoynx stratiotata may stimulate nutrient release and alter water quality (Grutters et al., 2016). These above mentioned examples demonstrate that the role of Lepidoptera in the functioning of freshwater ecosystems is probably vastly underestimated.

Our knowledge about the interactions of aquatic caterpillars with other animals, especially predators and parasites, is also very limited, but studies suggest that the caterpillars play an important role in the diet of some fish and invertebrates. Larvae of some beetles and dragonflies are also known to attack aquatic caterpillars, although there is no information about specific species or genera that prey on lepidopteran larvae (Agassiz, 1996). There is a single observation of $A$. ephemerella caterpillars that were attacked by hemipterans, water mites, and spiders (Buckingham and Ross, 1981), while eggs of this species were eaten by planarians. However, this observation was made in North America which is outside native European range of $A$. ephemerella (Batra, 1977). Tuskes (1977) reported high fish predation pressure on the algaescraping larvae of Petrophila confusalis. In addition, caterpillars of the closely related species $P$. truckeealis were found in the stomachs of perch (Lange, 1971). Some aquatic caterpillars were also recorded in the diet of a rainbow trout a species that was introduced to Hawaii (Englund and Polhemus, 2001). The larvae of C. lemnata and Elophila nymphaeata kept in the laboratory were eaten by carp, tench, roach, gudgeon or common bleak (Wojtusiak and Wojtusiak, 1960). It is worth remembering that laboratory observations may produce different results than those obtained under natural conditions. For example, Dorn et al. (2001) observed that caterpillars outside their tubes were eaten more often than those protected by cases, although results were different in the laboratory. What is more important is that these observations were based on a single experiment with only a small number of caterpillars. At the same time these observations showed that some fish are in fact able to consume caterpillars without swallowing the protective cases.

There is also very little data on the effects of parasitic hymenopterans (Ichneumonidae) and flies (Tachinidae) on aquatic caterpillars (Lange, 1956; Lange, 1971; Resh and Jamieson, 1988; Yoshida et al., 2011). No study has comprehensively analysed the pressure of fish or other predators and parasitoids on the populations of different moth species, or compared the predation on tube building species with those that do not hide inside any protective case. In at least some aquatic crambids the time needed for the construction of a protective case and the type of the material used can be very important as an element of a predator avoidance strategy (Müeller and Dearing, 1994).

Moreover, macrophytes themselves can provide good shelter from various threats (Dorn et al., 2001). In view of all the incomplete evidence, it is difficult to assess the importance of predation pressure during the early stages of evolution of the aquatic life style in Lepidoptera. It is equally difficult to theorize how the predation pressure could have influenced the development of defensive strategies, host plant preferences or the distribution along environmental gradients or within various microhabitats. Furthermore, information is lacking on the inter- and intraspecific competition in aquatic moths.

\section{Adults, eggs and pupae - life cycle under the water}

Many aquatic moths stay underwater during all the preimaginal stages. Adults of almost all these species are typical terrestrial insects. Females of some Acentropinae (e.g. genus Petrophila) may enter the water to lay eggs and stay submerged for a few hours, but this does not make them fully aquatic (Lange, 1956). Many aquatic moths lay eggs on the submerged side of floating leaves or stems by placing the abdomen beneath the water surface (Reichholf, 1970; Pabis, 2014). A truly aquatic adult form is found in only one species, A. ephemerella, the only species in the genus. In this species, aquatic brachypterous females swim using the last pair of legs, and they also have plastron structures for respiration. Along with hemipterans of the genus Aphelocheirus and some aquatic cave beetles, Acentria ephemerella is one of only a few insects that can stay under water throughout its entire life span (Carbonell et al., 2011; Miller and Bergsten, 2016). Such a mode of life strongly affects the dispersal ability of the moth; however, the second form of $A$. ephemerella female and all males are terrestrial and have fully developed wings. This unique mode of life is difficult to explain because, despite the relatively good knowledge about the host plants and life cycle of the species (both forms of females lay eggs on Potamogeton, Chara and Elodea; caterpillars are hydrophilous; copulation of the brachypterous females takes place close to the water surface; adult females live for only 1-2 days) (Berg, 1941; Kokociński, 1963; Choi et al., 2002; Speidel, 2002), there have been no detailed studies on factors affecting the development of these two different forms of $A$. ephemerella. In addition, no molecular or physiological research has been conducted on these morphotypes. Virtually nothing is known about the 
effects of physical and chemical factors (e.g. dissolved oxygen content or temperature in water) on the development time and divergence in the adult female morphology of this species. Some studies suggest that development of these two morphotypes is a relatively recent adaptation because the morphology of the compound eyes in the aquatic form is similar to the eye morphology of the terrestrial form; despite the obvious differences in the physical characteristics of the environment and biology of the two forms of the moth (Lau et al., 2007). The presence of the two morphotypes might be related to divergence in dispersal strategies. A. ephemerella is a small, delicate moth with limited flying ability, and can thus be blown far from the water by the wind (Berg, 1941), although adults have been observed engaging in active flight at relatively large distance of $1 \mathrm{~km}$ from water bodies (Pruffer, 1957). While the winged form allows for dispersal, the presence of the aquatic form minimizes the risk of being lost. Brachyptery can also be associated with the larger number of eggs produced (Roff, 1994), but in no study were the two forms compared with respect to this.

Most of the knowledge on adaptations of Lepidoptera to the aquatic environment concerns caterpillars. In only one study were egg adaptations examined. In E. nymphaeata air-filled structures located under the chorion and a mucus layer of the egg allowed for the uptake of air directly from plants (Barbier and Chauvin, 1974). Pupae are often hidden in various air-filled cocoons or in stems of aquatic plants (Lange, 1956; Reichholf, 1970; Speidel, 2002; Pabis, 2014). However, we do not know anything about the oxygen requirements and/or tempo of the developmental and metabolic processes of these pupae.

\section{So many or so few?}

There are at least 800 species of aquatic lepidopterans. On the other hand, when the number of evolutionary transfers from land to water is taken into account (members of three families only!), the number of truly aquatic moths is actually low compared to other groups of aquatic insects such as the Hemiptera, Coleoptera and Diptera (Jach and Balke, 2008; Polhemus and Polhemus, 2008). The number of evolutionary entries to the freshwater by insects is estimated to exceed 50 based on the review of the available phylogenetic studies (Dijkstra et al., 2014; Mitterboeck et al., 2016).

Knowledge of the phylogeny of the aquatic crambids is increasing (Solis, 2007; Regier et al., 2012; Liu et al., 2016), although it is still not detailed enough to enable us to develop scenarios concerning the natural history of aquatic species. It cannot be ruled out that similar adaptations occurred multiple times within the Crambidae. A recent study by Chen et al. (2017a), involving molecular data, suggests that the Nymphula-type caterpillar (with hydrophobic cuticle and open spiracle system) evolved from the Parapoynx-type larva (with tracheal gills and closed spiracles). Although the current state of biodiversity inventories in different regions of the world preclude the completion of any comprehensive zoogeographical studies; it is worth mentioning that only two genera, Parapoynx and Elophila, are cosmopolitan (Mey and Speidel, 2008). Since these two taxa probably represent the key evolutionary lines among aquatic moths, they should be in the focus of phylogeographic studies.
The most recent molecular analysis strongly supports monophyly of the Acentropinae (Regier et al., 2012). Moreover, the crambid subfamilies that can be defined as semi-aquatic or associated with moist habitats (Schoenobiinae and Midilinae) are very closely related to the Acentropinae, together forming, in the terminology of Regier et al. (2012), a "wet clade". The crambid subfamily Pyraustinae and the genus Paracles represent independent evolutionary events. Interesting results based on the analysis of molecular data showed that the semi-aquatic Hawaiian Hyposmocoma represent multiple entrances to and reversions from the aquatic life style. Although in this case the isolated nature of the Hawaiian ecosystem could have substantially influenced the evolution of these moths, since they most probably represent one of the early colonisers of the Hawaiian archipelago (Rubinoff, 2008). There are no other similar studies on semi-aquatic members of other families, but most of them probably represent relatively recent adaptations to the aquatic environment, which are observed in single species or genera only.

The near absence of adult aquatic moths can be relatively easily explained. Unlike the robust bodies of beetles and hemipterans which have a second pair of wings covered by the elytra, delicate wings of the moths are not a very good preadaptation to the aquatic environment. In the case of the Lepidoptera, still another important aspect of their biology could have affected their evolution in the aquatic environment - almost all caterpillars are phytophagous. Co-evolution with the angiosperms was most probably a key element of lepidopteran evolution for millions of years (Grimaldi and Engle, 2005). At the same time less than 1\% of the flowering plants can be considered aquatic (Vermeij and Dudley, 2000; Chambers et al., 2008), which substantially reduces the potential food base for the caterpillars. In fact, only a few of the Brazilian Acentropinae are carnivores that consume larvae of the Simuliidae (Solis, 2007). Representants of other aquatic insect orders are mostly detritivores, carnivores or parasitoids and are not dependent on the availability and diversity of macrophytes (Ward, 1992). In addition to the obvious osmotic limitations, the lack of appropriate food likely reduced the possibility of the marine environment being colonized by lepidopteran caterpillars; in general, the number of insects in the seas is very low and most of them are associated with the near shore zone (Ward, 1992). Some aquatic moth caterpillars such as $E$. nymphaeata were reported from brackish waters of a small Black Sea lagoon (Kovachev et al., 1999). Some other caterpillars of Acentropinae were recorded in estuaries or in brackish lakes (Ward, 1992).

\section{Concluding remarks}

Detailed phylogenetic studies, as well as studies on life cycles and evo-devo research are needed to understand the evolutionary processes that shaped the diversity and biology of aquatic and semi-aquatic moths. Genome sequencing of at least some taxa representing various ecological groups, especially from the Acentropinae, could also supply relevant data (Park et al., 2014; Ye and You, 2016; Chen et al., 2017a). To answer many important questions about the ecology and evolution of aquatic moths, life cycles should be studied and linked with the results of phylogenetic studies (genus and/or 
species level). Phylogenetic studies should include divergence time estimates using the molecular clock. Such studies would help us to understand the rate of evolutionary events, the order of appearance and importance of key morphological and behavioural adaptations, and enable recognition of the most important radiation centres. Studies of this kind should enhance our understanding of the colonization of remote islands since there are endemic species of the Acentropinae known from the Galapagos (Landry and Roque-Albelo, 2006) or Wallacea (Mey and Speidel, 2008). At the same time we do not know the life cycles of even some European species (Slamka, 1997; Speidel, 2002).

Even studies on distribution patterns, abundance or activity levels in relation to basic environmental factors (e.g. water chemistry, temperature, $\mathrm{pH}$, and food availability) and research on dispersal abilities are rare (Stoops et al., 1998; Wheeler and Halpern, 1999; van der Heide et al., 2006). For example, studies of the influence of temperature on grazing pressure can be very important in the context of climate warming (van der Heide et al., 2006); especially since moth caterpillars are a major group of aquatic herbivores. All these processes were probably important for the radiation and diversification of species in various microhabitats and for the selection of food plants. There is very limited knowledge on possible shifts between habitats or different types of water bodies (lotic or stagnant waters) and the related evolutionary processes. Semiaquatic forms should receive particular attention, because they represent the basic stages of adaptation to the aquatic environment and thus may serve as proxies of the early evolutionary processes.

Most ecological and life cycle studies of aquatic moths were carried out between the 1940s and 1980s, primarily on the European or North American faunas (e.g. Berg, 1941; Berg, 1950; McGaha, 1954; Lange, 1956; Reichholf, 1970; Barbier and Chauvin, 1974; Tuskes, 1977; Buckingham and Ross, 1981; Habeck, 1988 and references therein). Some of the studies date back to the beginning of last century (e.g. Welch, 1919; Welch and Sechon, 1928). Modern hydrobiologists seem to have neglected ecological studies of freshwater caterpillars. Most of the recent studies focus on taxonomy and biodiversity inventories, although some regions remain poorly explored $(e$. g. Chen et al., 2010; Schmitz and Rubinoff, 2011; Agassiz, 2012, 2014; Scholtens and Solis, 2015; Irungbam et al., 2016). The few ecological studies that have been published during the last 15 years often addressed the biology of the already relatively well-studied and common, mostly European species such as C. lemnata or A. ephemerella (e.g. van der Heide et al., 2006; Erhard et al., 2007; Miler et al., 2014; Pabis, 2014) or species treated as pests of cultivated aquatic plants, such as the common Parapoynx crisonalis (Li et al., 2017; Chen et al., $2017 b$ ). This situation might be due to the paucity of specialists, or the relative difficulty of carrying out long-term laboratory observations, and perhaps also due to the relatively minor economic importance of the insects in question, although they are sometimes used for biological control of selected macrophytes (Center and Hill, 2002; Bownes, 2010). Some of the aquatic caterpillars may also be regarded as pests of rice (Lange, 1956), but have still received rather minor attention (e.g. Pulin and Khound, 2000). Larvae of C. lemnata can drill holes in PVC foil (van der Velde, 1991) and therefore may have the potential to be used for plastic waste bio- degradation, as recently proposed for the pyralid Galleria mellonella (Bombelli et al., 2017).

There is also a great need for further taxonomic studies. Since identification of larvae is very difficult, descriptions of most species are based on the traditional morphotaxonomy of adult stages (Mey and Speidel, 2008). This results in erroneous placement of some species, belonging to other crambid subfamilies, within the Acentropinae (Yen et al., 2004; Mey and Speidel, 2010). Studies which provide detailed descriptions of caterpillars together with identification keys and good drawings are very scarce and tend to analyse only a very small number of species (Krampl, 1980; Vallenduuk and Cuppen, 2004; Habeck and Balciunas, 2005). A larger number of caterpillar descriptions together with studies of the biology of Australian Acentropinae were done by John Hawking, but the results are still unpublished (Agassiz, 2014). It is very important to include the integrative taxonomy methods (including barcoding) so that not only potential cryptic species are found, but so that caterpillars are linked with their respective imaginal stages. This would result in more comprehensive descriptions of species that would help ecologists in field and laboratory studies of the biology and life cycles. It will also allow to trace the origin of at least some non-indigenous species. At present there is only one similar integrative study that only focused on two species of Acentropinae (Solis et al., 2018). Aquatic and semi-aquatic moths are probably one of the most poorly studied ecological groups within the Lepidoptera. The potential for various studies on their ecology and evolution is great and untapped.

Acknowledgements. The study was supported by the University of Lodz internal funds. Thanks are due to anonymous reviewers for comments and critiques that helped to improve this article.

\section{References}

Adis J. 1983. Eco-entomological observations from the Amazon. IV. Occurrence and feeding habits of the aquatic caterpillar Palustra laboulbeni Bar, 1873 (Arctiidae: Lepidoptera) in the vicinity of Manaus, Brazil. Acta Amaz 13: 31-36.

Agassiz DJ. 1996. Lepidoptera Pyralidae (China Mark) moths. In: Nillson A., ed. Aquatic Insects of North Europe. A Taxonomic Handbook. Vol. 1. Stenstrup: Apollo Books, 257-263 pp.

Agassiz D. 2012. The Acentropinae (Lepidoptera: Pyraloidea: Crambidae) of Africa. Zootaxa 3494: 1-73.

Agassiz D. 2014. A preliminary study of the genus Nymphicula Snellen from Australia, New Guinea and the south Pacific (Lepidoptera: Pyraloidea: Crambidae: Acentropinae). Zootaxa 3774: 401-429.

Balmert A, Bohn HF, Ditsche-Kuru P, Barthlott W. 2011. Dry under water: comparative morphology and functional aspects of airretaining insect surfaces. $J$ Morphol 272: 442-451.

Barbier R, Chauvin G. 1974. The aquatic egg of Nymphula nymphaeata (Lepidoptera: Pyralidae). Cell Tissue Res. 149: 473-479.

Batra SWT. 1977. Bionomics of the aquatic moth Acentropus niveus (Olivier), a potential biological control agent for euroasian watermilfoil and hydrilla. N Y Entomol Soc 85: 143-152.

Berg K. 1941. Contributions to biology of the aquatic moth Acentropus niveus (Oliv.). Vidensk Medd Dansk Naturh Foren Kbh 105: 59-139. 
Berg CO. 1950. Biology of certain aquatic caterpillars (Pyralidae: Nymphula spp.) which feed on Potamogeton. Trans Am Microsc Soc 69: 254-266.

Bombelli P, Howe CJ, Bertocchini F. 2017. Polyethylene biodegradation by caterpillars of the wax moth Galleria mellonella. Curr Biol 27: 292-293.

Bownes A. 2010. Asian aquatic plant moth Parapoynx diminutalis, accidentally introduced earlier, contributes to control of an aquatic weed Hydrilla verticillata in South Africa. Afr J Aquat Sci 35: 307-311.

Brambila J, Stocks I. 2010. The European Pepper Moth, Duponchelia fovealis Zeller (Lepidoptera: Crambidae), a Mediterranean Pest Moth Discovered in Central Florida. Florida Department of Agriculture and Consumer Services.

Brito R, De Prins J, De Prins W, Mielke OHH, Gonçalves GL, Moreira GRP. 2016. Extant diversity and estimated number of Gracillariidae (Lepidoptera) species yet to be discovered in the Neotropical region. Rev Bras Etomol 60: 275-283.

Buckingham GR, Ross BM. 1981. Notes on the biology and host specificity of Acentria nivea (=Acentropus niveus). J Aquat Plant Manag 19: 32-36.

Carbonell JA, Abellan P, Arribas P, Elder JF, Millan A. 2011. The genus Aphelocheirus Westwood, 1833 (Hemiptera: Aphelocheiridae) in the Iberian Peninsula. Zootaxa 2771: 1-16.

Carter DJ, Hargreaves B. 1994. Field Guide to the Caterpillars of Britain and Europe. London: Harper Collins Publishers.

Center TD, Hill MP. 2002. Field efficacy and predicted host range of the pickerelweed borer, Bellura densa, a potential biological control agent of water hyacinth. BioControl 47: 231-243.

Chambers PA, Lacoul P, Murphy KJ, Thomaz SM. 2008. Global diversity of aquatic macrophytes in freshwater. Hydrobiologia 595: 9-26.

Chen Q, Chen ZS, Gu XS, Ma L, Wang X, Huang GH. 2017a. The complete mitogenome of Parapoynx crisonalis (Walker, 1859) (Lepidoptera: Crambidae), with phylogenetic relationships amongst three Acentropinae larval forms. Aquat Insects 38: 79-91.

Chen F, Chunsheng W, Xue D. 2010. A review of the genus Elophila Hubner, 1822 in China (Lepidoptera: Crambidae: Acentropinae). Aquat Insects 32: 35-60.

Chen Q, Ni L, Xing W, Li M, Jian-Bin H, Guo-Hua H. 2017b. Agestage, two-sex life table of Parapoynx crisonalis (Lepidoptera: Pyralidae) at different temperatures. PLoS One 12: e0173380.

Choi C, Bareiss C, Walenciak O, Gross EM. 2002. Impact of polyphenols on growth of the aquatic herbivore Acentria ephemerella. J Chem Ecol 28: 2245-2256.

Davis DR, Landry JF. 2012. A review of the North American genus Epimartyria (Lepidoptera, Micropterigidae) with a discussion of the larval plastron. ZooKeys 183: 37-83.

Dijkstra KDB, Monaghan MT, Pauls SU. 2014. Freshwater biodiversity and aquatic insects diversification. Annu Rev Entomol 59: $143-163$.

Dorn NJ, Cronin G, Lodge DM. 2001. Feeding preferences and performance of an aquatic lepidopteran on macrophytes: plant hosts as food and habitat. Oecologia 128: 406-415.

Englund RA, Polhemus DA. 2001. Evaluating the effects of introduced rainbow trout (Oncorhynchus mykiss) on native stream insects on Kauai Island, Hawaii. J Insect Conserv 5: 265-281.

Erhard D, Pohnert G, Gross EM. 2007. Chemical defense in Elodea nuttalii reduces feeding and growth of aquatic herbivorous Lepidoptera. J Chem Ecol 33: 1646-1661.

Farahpour-Haghani A, Hassanpour M, Alinia F, Nouri-Ganbalani G, Razmjou J, Agassiz D. 2017. Water ferns Azolla spp. (Azollaceae) a new host plants for the small China-mark moth, Cataclysta lemnata (Linnaeus, 1758) (Lepidoptera, Crambidae, Acentropinae). Nota Lepi 40: 1-13.

Flynn MR, Bush JWM. 2008. Underwater breathing: the mechanics of plastron respiration. J Fluid Mech 608: 275-296.

Grimaldi D, Engle MS. 2005. Evolution of the Insects. New York: Cambridge University Press.

Gross EM, Johnson RL, Hairston NG. 2001. Experimental evidence for changes in submersed macrophyte species composition caused by the herbivore Acentria ephemerella (Lepidoptera). Oecologia 127: 105-114.

Gross EM, Feldbaum C, Choi C. 2002. High abundance of herbivorous Lepidoptera larvae (Acentria ephemerella Denis and Schifermüller) on submersed macrophytes in Lake Constance (Germany). Arch Hydrobiol 155: 1-21.

Grutters BMC, Gross EM, Bakker ES. 2016. Insect herbivory on native and exotic aquatic plants: phosphorus and nitrogen drive insect growth and nutrient release. Hydrobiologia 778: 209-220.

Habeck DH. 1988. Neargyractis slossonalis (Lepidoptera: Pyralidae, Nymphulinae): larval description and biological notes. Fla Entomol 71: 588-592.

Habeck DH, Balciunas JK. 2005. Larvae of Nymphulinae (Lepidoptera: Pyralidae) associated with Hydrilla verticilata (Hydrocharitaceae) in North Queensland. Aust J Entomol 44: 354-363.

Habeck DH, Cuda JP, Weeks ENI. 2017. Waterlily leafcutter, Elophila obliteralis (Walker) (Insecta: Lepidoptera: Crambidae: Acentropinae). Featured Creatures from the Entomology and Nematology Department, Florida Cooperative Extension Service, Institute of Food and Agricultural Sciences, University of Florida.

Hannemann HJ. 1967. Lepidoptera. In: Illies J, ed. Limnofauna Europea. Stuttgart: Gustav Fischer Verlag.

Harms NE, Grodowitz MJ. 2009. Insect herbivores of aquatic and wetland plants in the United States: a checklist from literature. $J$ Aquat Plant Manage 47: 73-96.

Irungbam JS, Chib MS, Wangdi K. 2016. Taxonomic review of the superfamily Pyraloidea in Bhutan (Lepidoptera). J Asia Pac Biodivers 9: 355-382.

Jach MA, Balke M. 2008. Global diversity of water beetles (Coleoptera) in freshwater. Hydrobiologia 595: 419-442.

Kokociński W. 1963. Remarks on biology of Acentropus niveus Oliv. (Lepidoptera, Pyralidae). Pol Pis Entomol 33: 233-242.

Kovac D, Jelínek J, Hashim R, Wiwatwitaya D. 2007. Transition from bamboo sap to water: aquatic habits in the sap beetle Amphicrossus japonicus (Coleoptera: Cucujoidea: Nitidulidae). Eur J Entomol 104: 635-638.

Kovachev S, Stoichev S, Haindijeva V. 1999. The zoobenthos of several lakes along the Northern Bulgarian Black Sea Coast. Lauterbornia 35: 33-38.

Krampl F. 1980. Rád motyli - Lepidoptera. In: Rozkošný R, ed. Klíč Vodních Larev Hmyzu. Praha: Československá Akademie Věd., 221-225 pp.

Kristensen NP, Scoble MJ, Karsholt O. 2007. Lepidoptera phylogeny and systematics: the state of inventorying moth and butterfly diversity. Zootaxa 1668: 699-747.

Landry B, Roque-Albelo L. 2006. The Acentropinae and Musotiminae (Lepidoptera, Pyralidae) of the Galapagos Islands, Ecuador. Zootaxa 1354: 45-56.

Lange WH. 1956. A generic revision of the aquatic moths of North America: (Lepidoptera: Pyralidae, Nymphulinae). Wasmann J Biol 14: $59-144$.

Lange WH. 1971. Aquatic Lepidoptera. In: Usinger RL, ed. Aquatic Insects of California with Keys to North American Genera and California Species. Berkeley, Los Angeles and London: University of California Press, 271-288 pp. 
Lau TF, Gross EM, Meyer-Rochow VB. 2007. Sexual dimorphism and light/dark adaptation in the compound eyes of male and female Acentria ephemerella (Lepidoptera: Pyraloidea: Crambidae). Eur J Entomol 104: 459-470.

Li N, Chen O, Zhu J, Wang X, Huang JB, Huang GH. 2017. Seasonal dynamics and spatial distribution patterns of Parapoynx crisonalis (Lepidoptera: Crambidae) on water chestnuts. PLoS One 12: e 0184149.

Litsinger JA, Chantarapraha N. 1995. Developmental biology and host range of Parapoynx fluctuosalis and P. diminutalis ricefield caseworms. Int J Trop Insect Sci 16: 1-11.

Liu QN, Chai XY, Bian DD, Zhou CL, Tang BP. 2016. The complete mitochondrial genome of Plodia interpunctella (Lepidoptera: Pyralidae) and comparisons with other Pyraloidea insects. Genome 59: 37-49.

McGaha YJ. 1954. Contribution to the biology of some Lepidoptera which feed on certain aquatic flowering plants. Trans Am Microsc Soc 73: 167-177.

Meneses AR, Bevilaqua MVO, Hamada N, Querino RB. 2013. The aquatic habit and host plants of Paracles klagesi (Rotschild) (Lepidoptera: Erebidae, Arctiinae) in Brazil. Rev Bras Entomol 57: 350-352.

Messner B, Adis J. 1987. Die Plastronstrukturen der submers lebenden neotropischen Bärenraupe von Palustra laboulbeni Bar, 1873 (Lepidoptera: Arctiidae). Zool Jahrb Abt Anat Ontog Tiere 115: 531-538.

Mey W, Speidel W. 2008. Global diversity of butterflies (Lepidoptera) in freshwater. Hydrobiologia 595: 521-528.

Mey W, Speidel W. 2010. Malicyella gen. nov. - a new moth genus in the family Crambidae (Lepidoptera, Pyraloidae) from South-East Asia. Denisia 29: 215-222.

Miler O, Gross EM, Straile D. 2014. Small-scale variation in sexual size dimorphism and sex ratio in the aquatic moth Acentria ephemerella Denis and Schiffermuller, 1775 (Lepidoptera: Crambidae). Aquat Insects 36: 187-199.

Miller KB, Bergsten J. 2016. Diving beetles of the World. Systematics and Biology of the Dytiscidae. Baltimore: Johns Hopkins University Press.

Mitterboeck TF, Fu J, Adamowicz SJ. 2016. Rates and patterns of molecular evolution in freshwater versus terrestrial insects. Genome 59: 968-980.

Müeller UG, Dearing MD. 1994. Predation and avoidance of tough leaves by aquatic larvae of the moth Parapoynx rugosalis (Lepidoptera: Pyralidae). Ecol Entomol 19: 155-158.

Nowacki J. 1998. The Noctuids (Lepidoptera, Noctuidae) of Central Europe. Bratislava: Frantisek Slamka.

Pabis K. 2014. Life cycle, host plants and abundance of caterpillars of the aquatic moth Cataclysta lemnata (Lepidoptera: Crambidae) in the post-glacial lake in Central Poland. North-West J Zool 10: 441-444.

Park JS, Kim MJ, Kim SS, Kim I. 2014. Complete mitochondrial genome of an aquatic moth, Elophila interruptalis (Lepidoptera: Crambidae). Mitochondrial DNA 25: 275-277.

Pulin P, Khound JN. 2000. Biology of rice caseworm Nymphula depunctalis (Guenee). J Agric Sci Soc North-East India 13: 119-121.

Petit C, Le Ru B, Dupas S, Frerot B, Ahuya P, Kaiser-Arnauld LHM, Calatayud PA. 2015. Influence of dietary experience on the induction of preference of adult moths and larvae for a new olfactory cue. PLoS One 10: e 0136169.

Polhemus JT, Polhemus DA. 2008. Global diversity of true bugs (Heteroptera; Insecta) in freshwater. Hydrobiologia 595: 379-391.

Pruffer J. 1957. Pełnoskrzydłe samice Acentropus niveus Oliv. pod Toruniem. Pol Pism Entomol 5: 23-29.
Regier JC, Mitter C, Solis MA, Hayden JE, Landry B, Nuss M, Simonsen TJ, Yen SH, Zwick A, Cummins MP. 2012. A molecular phylogeny for the pyraloid moths (Lepidoptera: Pyraloidea) and its implications for higher-level classification. Syst Entomol 37: 635-656.

Reichholf J. 1970. Untersuchungen zur Biologie des Wasserschmerlings Nymphula nymphaeata L. (Lepidoptera, Pyralidae). Int Rev Ges Hydrobiol 55: 687-728.

Reichholf J. 1976. Die Feinstruktur der Cuticula hydrophiler und hydrophober Raupen des Wasserschmetterlings Nymphula nymphaeata (Lepidoptera: Pyralidae: Nymphulinae). Entomol German 2: 258-261.

Resh VH, Jamieson W. 1988. Parasitism of the aquatic moth Petrophila confusalis (Lepidoptera: Pyralidae) by the aquatic wasp Tanychella pilosa (Hymenoptera: Ichneumonidae). Entomol News 99: $185-188$.

Roff DA. 1994. The evolution of flightlessness: is history important? Evol Ecol 8: 639-657.

Rubinoff D. 2008. Phylogeography and ecology of an endemic radiation of Hawaiian aquatic case-bearing moths (Hyposmocoma: Cosmopterigidae). Philos Trans $R$ Soc Lond B Biol Sci 363: 3459-3465.

Russell JA, Funaro CF, Giraldo YM, Goldman-Huertas B, Suh D, Kronauer DJC, Moeau CS, Pierce NE. 2012. A veritable menagerie of heritable bacteria from ants, butterflies, and beyond: broad molecular surveys and a systematic review. PLoS One 7: e 51027.

Schmitz P, Rubinoff D. 2011. The Hawaiian amphibious caterpillar guild: new species of Hyposmocoma (Lepidoptera: Cosmopterigidae) confirm distinct aquatic invasions and complex speciation patterns. Zool J Linn Soc 162: 15-42.

Scholtens BG, Solis MA. 2015. Annotated check list of the Pyraloidea (Lepidoptera) of America North of Mexico. ZooKeys 535: 1-1136.

Schwentner M, Combosch DJ, Nelson JP Giribet G. 2017. A phylogenomic solution to the origin of insects by resolving crustacean-hexapod relationships. Curr Biol 27: 1818-1824.

Scoble MS. 1995. The Lepidoptera Form, Function and Diversity. New York: Oxford University Press.

Slamka F. 1997. Die Zunsleratigen (Pyraloidea) Mitteleuropas. Bratislava: Frantisek Slamka.

Smolders A, van der Velde G. 1996. Spilosoma lubricipeda (Lepidoptera: Arctiidae) feeding on the aquatic macrophyte Stratiotes aloides. Entomol Berichten Amsterdam 56: 33-34.

Solis MA. 2007. Phylogenetic studies and modern classification of the Pyraloidea (Lepidoptera). Revi Colomb Entomol 33: 1-9.

Solis MA, Harms NE, Phillips-Rodriguez E, Scheffer SJ, Lewis ML, Janzen DH, Hallwachs W, Metz MA. 2018. Aquatic larvae of two acentropines, Usingeriessa onyxalis (Hampson) and Oxyelophila callista (Forbes) (Lepidoptera: Crambidae). Proc Entomol Soc Wash 120: 180-195.

Speidel W. 2002. Insecta: Lepidoptera: Crambidae: Acentropinae. In: Schwoerbel J, Zwick P, eds. Süßwasserfauna von Mitteleuropa. Heidelberg, Berlin: Spektrum, 87-148 pp.

Sterling P, Parsons M. 2012. Field Guide to the Micromoths of Great Britain and Ireland. Gillingham: British Wildlife Publishing.

Stoops CA, Adler PH, McCreadie JW. 1998. Ecology of aquatic Lepidoptera (Crambidae: Nymphulinae) in South Carolina, USA. Hydrobiologia 379: 33-40.

Tuskes PM. 1977. Observations on the biology of Parargyractis confusalis, an aquatic pyralid (Lepidoptera: Pyralidae). Can Entomol 109: 695-699. 
Vallenduuk HJ, Cuppen MJ. 2004. The aquatic living caterpillars (Lepidoptera: Pyraloidea: Crambidae) of Central Europe. A key to the larvae and autecology. Lauterbornia 49: 1-17.

van der Heide T, Roijackers RMM, Peeters ETHM, van Nes EH. 2006. Experiments with duckweed-moth systems suggest that global warming may reduce rather than promote herbivory. Freshwater Biol 51: 110-116.

van der Velde G. 1988. Cataclysta lemnata L. (Lepidoptera, Pyralidae) can survive for several years consuming macrophytes other than Lemnaceae. Aquat Bot 31: 183-189.

van der Velde, G. 1991. Rupsen van Cataclysta lemnata (L.) (Lepidoptera, Pyralidae) kunnen PVC vijverfolie perforeren. Entomol Ber 51: 94-95.

Vermeij GJ, Dudley R. 2000. Why are there so few evolutionary transitions between aquatic and terrestrial ecosystems? Biol J Linn Soc 70: 541-554.

Walenciak O, Zwisler W, Gross EM. 2002. Influence of Myriophyllum spicatum-derived tannins on gut microbiota of its herbivore Acentria ephemerella. J Chem Ecol 28: 2045-2056.

Ward JW. 1992. Aquatic Insect Ecology. New York, Chichester, Brisbane, Toronto, Singapore: John Wiley and Sons, Inc.

Welch PS. 1919. The aquatic adaptations of Pyrausta penitalis Grt. (Lepidoptera) and their respiratory significance. Ann Entomol Soc Am 12: 213-226.
Welch PS, Sehon GL. 1928. The periodic vibratory movements of the larva of Nymphula maculalis Clemens (Lepidoptera) and their respiratory significance. Ann Entomol Soc Am 21: 243-258.

Wheeler GS, Halpern MD. 1999. Compensatory responses of Samea multiplicalis larvae when fed leaves of different fertilization levels of the aquatic weed Pista stratioides. Entomol Exp Appl 92: 205-216.

WojtusiakH, Wojtusiak RJ. 1960. Biologia, występowanieiuzytkownos ć motyli wodnych $\mathrm{z}$ podrodziny Hydrocampinae w stawach dos wiadczalnych PAN Ochaby. Pol Arch Hydrobiol 8: 253-260.

Ye F, You P. 2016. The complete mitochondrial genome of Paracymoriza distinctalis (Lepidoptera: Crambidae). Mitochondrial DNA Part A 27: 28-29.

Yen SH, Solis MA, Goolsby JA. 2004. Austromusotima, a new Musotiminae genus (Lepidoptera: Crambidae) feeding on old world climbing fern, Lygodium microphyllum (Schizaeaceae). Ann Entomol Soc Am 97: 397-410.

Yoshida T, Nagasaki O, Hirayama T. 2011. A new species of the genus Apsilops Forster (Hymenoptera: Ichenumonidae: Cryptinae) from Japan; parasitoid of an aquatic crambid moth. Zootaxa 2916: 4150.

Yoshiyasu, Y. 1980. A systematic study of the Genus Nymphicula Snellen from Japan (Lepidoptera: Pyralidae). Tyô to Ga 31: 1-28.

Cite this article as: Pabis K. 2018. What is a moth doing under water? Ecology of aquatic and semi-aquatic Lepidoptera. Knowl. Manag. Aquat. Ecosyst. 419: 42. 